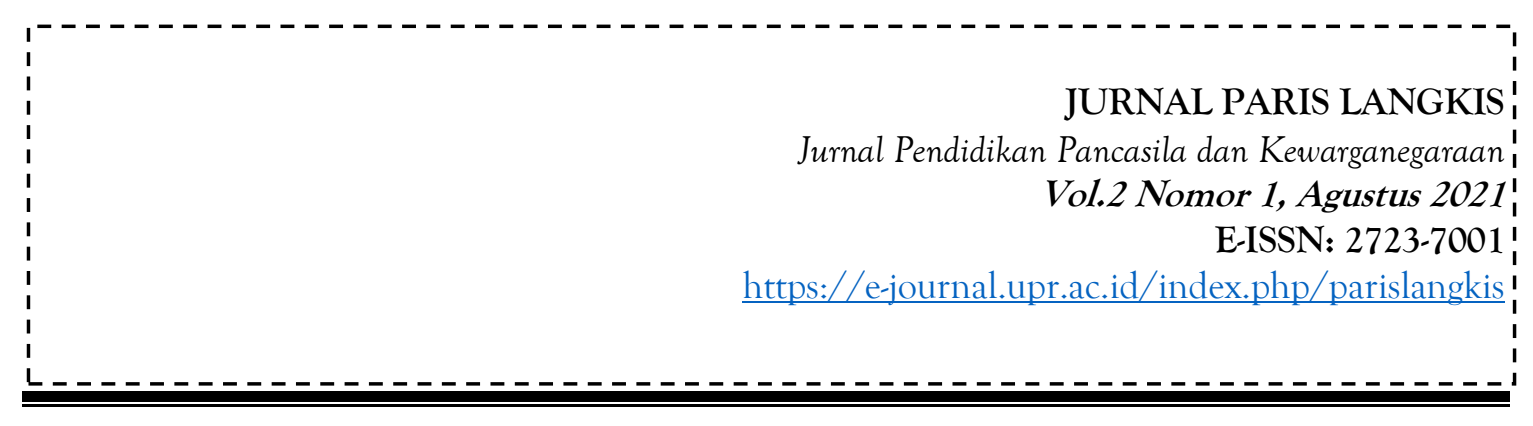

\title{
PENGARUH KEMANDIRIAN BELAJAR PESERTA DIDIK DAN LATAR BELAKANG PENDIDIKAN ORANG TUA TERHADAP HASIL BELAJAR KELAS IV DI SDIT AL-MADINA PURWOREJO
}

\author{
Selfi Faulina Safitri ${ }^{1}$, Suyoto ${ }^{2}$, Nurhidayati ${ }^{3 .}$ \\ ${ }^{123}$ Universitas Muhammadivah Purworejo \\ Email:selfifaulin@gmail.com ${ }^{1}$, suyoto.ump@gmail.com²,nurhidayati@umpwr.ac.id ${ }^{3}$.
}

\begin{abstract}
Abstrak
Adanya wabah Covid-19 mengharuskan sistem pembelajaran di sekolah berbasis daring. Pada dasarnya, pembelajaran daring tentu menuntut peserta didik lebih mandiri dalam belajar dan perlu adanya bimbingan orang tua, terutama pada jenjang sekolah dasar. Upaya dalam mengetahui secara akurat, maka dilakukan penelitian untuk menguji pengaruh kemandirian belajar peserta didik dan latar belakang pendidikan orang tua terhadap hasil belajar kelas IV. Tujuan penelitian ini yaitu untuk mengetahui pengaruh: 1) Kemandirian belajar peserta didik terhadap hasil belajar IPA, 2) Latarbelakang pendidikan orang tua terhadap hasil belajar IPA, 3) Kemandirian belajar peserta didik dan latarbelakang pendidikan orang tua terhadap hasil belajar IPA. Pendekatan yang digunakan berupa pendekatan kuantitatif dengan teknik regresi ganda. Metode pengumpulan data dilakukan dengan teknik observasi, angket, dan dokumentasi. Hasil penelitian menunjukkan: 1) Tidak terdapat pengaruh antara kemandirian belajar peserta didik terhadap hasil belajar IPA kelas IV, dengan nilai koefisien sebesar 0,342 dan Sig 0,108>0,05 dengan kontribusi sebesar 1,02\%,2) Tidak terdapat pengaruh antara latarbelakang pendidikan orang tua terhadap hasil belajar IPA kelas IV, dengan nilai koefisien sebesar -0,101 dan Sig 0,624 $>0,05,3)$ Tidak terdapat pengaruh antara kemandirian belajar peserta didik dan latarbelakang pendidikan orang tua terhadap hasil belajar IPA kelas IV, dengan nilai nilai $F_{\text {hitung }}$ sebesar $-0,101<$ $\mathrm{F}_{\text {tabel }} 3,44$ dan Sig 0,624>0,05.
\end{abstract}

Kata kunci: kemandirian belajar; Latarbelakang pendidikan orang tua; hasil belajar IPA.

\section{Abstract}

The covid-19 outbreak requires online school learning systems. Basically, online learning certainly requires learners to be more self-reliant in learning and need parental guidance, especially at the bottom of elementary school. Efforts to know accurately, studies are conducted to test the impact of self-reliance learn learners and parents' educational backgrounds on the result of studying class iv. The purpose of this study is to know the impact: 1) the self-reliance is learning the students to the learned science, 2) the parents' education background to the learned science, 3) the learning self-reliance The approach used was a quantitative

Paris Langkis

Vol.2 Nomor 1, Agustus 2021 
approach with a double regression technique. Data collection methods are done using observation, angket, and documentation techniques. Research shows: 1) there is no effect between the learning ability of learners on learning science class $i v$, with a coefficient score of 0.342 and sig $0.108>0.05$ with a contribution of $1,02 \%, 2)$ with no influence between the background of a parent's education on the iv science study, with a coefficient of -0.101 and sig $0.624>0.05,3$ ) there is no effect between learner 's learning independence and a parent's background on the result of the study of science class iv, with a fcalculating value of $-0.101<$ fchart 3.44 and sig 0,624>0,05.

Keyword: learning self-reliance; Background of parental education; Science-study results.

\section{A. PENDAHULUAN}

Berdasarkan Sitem Pendidikan Nasional (Sidiknas) yang tercantum dalam UU RI Nomor 20 Tahun 2003 Pasal 3, pendidikan berfungsi mengembangkan kemampuan dan membentuk watak serta peradaban bangsa yang bermartabat dalam rangka mencerdaskan kehidupan bangsa. Upaya dalam mencerdaskan kehidupan bangsa diperlukan adanya perubahan sistem dan peningkatan kualitas pendidikan untuk memperoleh hasil belajar yang maksimal. Menurut Kunandar (2013: 62), hasil belajar merupakan kemampuan atau kompetensi tertentu baik kognitif, afektif maupun psikomotorik yang telah ditempuh atau dikuasai peserta didik setelah mengikuti proses belajar mengajar. Sudjana (2012: 1) juga mengungkapkan bahwa hasil belajar merupakan kemampuan-kemampuan yang dimiliki peserta didik setelah melalui pengalaman belajar sesuai dengan materi yang telah di pelajari. Keberhasilan belajar dapat dilihat dari tinggi rendahnya nilai yang dicapai melalui daya serap pe serta prestasi hasil belajar yang dinyatakan dalam bentuk skor berupa rapor. Keberhasilan belajar dapat dipengaruhi oleh banyak faktor yaitu faktor internal dan eksternal. Menurut Slameto (2015: 54), faktor internal yang dapat mempengaruhi hasil belajar dapat meliputi motivasi, sikap, minat, perhatian, dan kemandirian belajar peserta didik, sedangkan faktor eksternal berhubungan dengan keluarga, guru, teman sepermainan, lingkungan. Untuk mewujudkan suatu keberhasilan yang diperoleh peserta didik maka perlu adanya kerja sama antara guru, orang tua, dan yang terpenting adalah peserta didik itu sendiri.

Salah satu faktor penting yang harus diperhatikan untuk mencapai hasil belajar yang baik yaitu adanya kemandirian belajar peserta didik. Menurut Suhandi dan Kurniasri (2019: 126) kemandirian belajar merupakan faktor yang menentukan keberhasilan peserta didik dalam belajarnya. Sehingga penting bagi peserta didik memiliki sikap kemandirian belajar agar keberhasilan belajar yang diinginkan dapat tercapai dengan baik. Kemandirian belajar dapat diwujudkan dengan adanya rasa tanggung jawab, bersikap aktif dan kreatif dan mampu mengatasi masalah yang sedang dihadapi (Wiaya \& Putra, 2021). Seseorang yang memiliki kemandirian belajar cenderung dapat memiliki kemampuan untuk bisa mengatur perasaanya tanpa ada pengaruh dari orang lain. Basir (Ningsih dkk 2017: 76) menyampaikan bahwa kemandirian belajar diartikan sebagai suatu proses belajar yang berasal dari dorongan dan kemauan diri sendiri didasari tanggung jawab yang berasal dari hati untuk mencapai tujuan tertentu dalam belajar. Senada dengan ini, peran orang tua sangat dibutuhkan dalam menumbuhkan kemandirin belajar anak. Adanya kebiasaan 
mandiri, maka anak akan terbiasa mengerjakan segala sesuatu sesuai dengan kemampuan yang dimilikinya. Peserta didik yang memiliki kemandirian belajar tinggi akan berusaha menyelesaikan tugas yang diberikan guru dengan menggunakan kemampuan yang dimiliki. Berbeda halnya dengan peserta didik yang memiliki kemandirian belajar yang rendah maka akan bergantung pada orang lain.

Surat edaran Kemendikbud Nomer 4 Tahun 2020 menyampaikan tentang adanya sistem pembelajaran daring, salah satunya pada jenjang pendidikan sekolah dasar. Hal ini tentu disebabkan karena adanya penyebaran virus Covid-19. Mengingat karakteristik peserta didik sekolah dasar, tentu sangat membutuhkan bimbingan orang tua guna melaksanakan sistem pembelajaran di rumah. Upaya untuk mencapai tingkat keberhasilan belajar yang maksimal, latar belakang pendidikan orang tua menjadi pendorongnya. Orang tua yang dimaksud yaitu terdiri dari 2 individu, yaitu ibu atau ayah. Namun, sebagai orang yang mempunyai penuh kasih sayang, ibu merupakan orang yang paling dekat dengan anak dibandingkan dengan ayah. Hal ini sejalan dengan pendapat Hurlock (Cholifah dkk, 2016: 486), bahwa lingkungan yang terdekat dengan anak adalah keluarga. Keluarga dan latar belakang pendidikan orang tua merupakan salah satu faktor yang mempengaruhi tingkat keberhasilan prestasi belajar anak. Orang tua yang memiliki latarbelakang pendidikan tinggi terhadap cara mendidik, mengasuh dan memantau perkembangan anak, mengajarkan pelajaran sekolah, memungkinkan memberi pengaruh besar bagi proses pendidikan anaknya. Orang tua yang memiliki latarbelakang pendidikan tinggi tentu memiliki pengalamah memnempuh pendidikan lebih banyak yang diperlukan untuk memfasilitasi sarana belajar anak. Orang tua yang memiliki pendidikan yang baik, umumnya bersifat terbuka dan bisa mengajarkan anak hal-hal yang positif. Sebaliknya, jika orang tua memiliki pendidikan yang kurang baik, maka sikap orang tua akan terlihat cuek dan kurang perduli atas permasalahan anak yang ada di sekolah, terutama perolehan hasil belajarnya yang kurang.

Berdasarkan wawancara dan observasi awal pada tanggal 12 Oktober 2020 pada pendidik kelas IV SDIT Al-Madina Purworejo, terdapat kenyataan bahwa hasil belajar peserta didik pada mata pelajaran IPA bervariasi. Pada penilaian tengah semester ganjil, persentase peserta didik yang sudah mencapai KKM dalam mata pelajaran IPA yaitu sebesar 29\% sedangkan 70\% sisanya merupakan persentase siswa yang belum tuntas. Hal lain yang disampaikan, bahwa selama pembelajaran daring sangat membutuhkan kemandirian belajar guna menunjang pembelajaran di rumah. Sikap mandiri dapat dilakukan dalam hal mengerjakan pekerjaan rumah (PR). Selama pembelajaran daring, masih banyak peserta didik yang pekerjaan rumahnya dikerjakan oleh orang tuanya. Latar belakang pendidikan orang tua kelas IV SDIT Al-Madina Purworejo rata-rata merupakan Sekolah Menengah Atas (SMA) dan Perguruan Tinggi, walaupun pada akhirnya banyak yang hanya menjadi ibu rumah tangga.

Berdasarkan uraian yang telah dipaparkan, peneliti tertarik untuk melakukan penelitian lebih lanjut dengan meneliti ada atau tidaknya pengaruh antara kemandirian belajar peserta didik dan latar belakang pendidikan orang tua terjadap hasil belajar IPA kelas IV SDIT Al-Madina Purworejo. Tujuan dari penelitian ini yaitu untuk mengetahui pengaruh: (1) kemandirian belajar peserta didik terhadap hasil belajar IPA kelas IV SDIT Al-Madina Purworejo, (2) latarbelakang pendidikan orang

Paris Langkis

Vol.2 Nomor 1, Agustus 2021 
tua terhadap hasil belajar IPA kelas IV SDIT Al-Madina Purworejo, (3) kemandirian belajar peserta didik dan latarbelakang pendidikan orang tua terhadap hasil belajar IPA kelas IV SDIT Al-Madina Purworejo.

\section{B. KAJIAN TEORI}

\section{Kemandirian Belajar}

Menurut Brookfield (Suharno, 2016: 161), kemandirian belajar merupakan kesadaran diri yang digerakan oleh diri sendiri untuk mencapai tujuan tertentu. Seseorang yang mempunyai sikap kemandirian akan berusaha mencari dan mengembangkan sesuatu hal dengan caranya sendiri untuk mencapai tujuan dan hasil yang dituju. Hal ini senada dengan pendapat Imron (2016: 143), bahwa kemandirian merupakan kegiatan belajar dengan inisitif sendiri. Keadaan ini terbiasa dilakukan jika peserta didik terus melatih dan membiasakan diri belajar dengan caranya sendiri. Sikap mandiri yang dimiliki seseorang tersebut membuatnya terbiasa tidak bergantung dengan orang lain. Berbeda dengan anak yang tidak mandiri mereka selalu bergantung dengan orang lain. Sejalan dengan ini, Uno (Ranti, 2017: 75), menyampaikan bahwa kemandirian belajar merupakan kemampuan yang bertujuan untuk mengendalikan diri sendiri dalam bertindak, berpikir agar tidak merasa bergantung kepada orang lain. Peserta didik harus memiliki kesadaran untuk belajar serta menentukan langkahlangkah apa saja yang harus diambil dalam kegiatan belajarnya. Terkait dengan ini, diperlukan indikator untuk mengukur kemandirian belajar yang disampaikan oleh Wahyuningsih (2020: 2), yaitu: (1) memiliki inisiatif untuk merencanakan strategi belajar, (2) mengatur dan mengarahkan diri untuk belajar, (3) tidak bergantung kepada orang lain, (4) memiliki tanggung jawab terhadap dirinya sendiri dalam belajar.

\section{Latarbelakang Pendidikan Orang Tua}

Pendidikan dapat diartikan sebagai suatu upaya seseorang dalam meningkatkan kepribadian diri sesuai dengan nilai moral yang terkandung dalam masyarakat dan budaya (Djamaluddin, 2014: 130). Hal ini tentu bertujuan untuk mengubah sikap, perilaku, serta pola pikir agar lebih baik lagi. Menurut Jhon Dewey (Chomaidi dan Salamah, 2018: 9), pendidikan adalah suatu proses pengalaman yang di peroleh dalam kehidupan sesuai dengan masa pertumbuhan. Penjelasan lebih lengkap dikemukakan oleh Langeveld (Chomaidi dan Salamah, 2018: 3), bahwa pendidikan adalah setiap usaha berupa perlindungan yang di berikan kepada anak menuju kedewasaan. Pengetahuan dan keterampilan yang didapat kemudian turunkan dari generasi ke generasi berikutnya melalui pengajaran, penelitian dan pelatihan. Poerbakawatja dan Harahap (Syah, 2019: 11) juga mengatakan bahwa pendidikan merupakan usaha yang dilakukan secara sengaja oleh orang dewasa untuk meningkatkan kedewasaan anaknya agar dapat bertanggung jawab terhadap semua perbuatannya. Orang dewasa yang dimaksud adalah orang tua, guru sekolah, kyai dalam lingkungan keagamaan dan sebagainya yang mempunyai kewajiban untuk mendidik.

Sisdiknas Pasal 13 dan 14 menjelaskan mengenai jenjang pendidikan sebagai berikut: (1) jenjang pendidikan dasar, (2) jenjang pendidikan menengah, dan (3) jenjang pendidikan tinggi. Pendidikan dasar adalah pendidikan yang memberikan 
pengetahuan dan keterampilan dalam menumbuhkan sikap dasar yang diperlukan di lingkungan masyarakat dalam rangka mempersiapkan peserta didik untuk mengikuti pendidikan menengah, dan implikasinya berupa jenjang SD. Pendidikan menengah adalah pendidikan yang mempersiapkan peserta didik menjadi anggota masyarakat yang memiliki kemampuan dan pengembangan lebih lanjut, dan implikasinya berupa jenjang SMP SMA sederajat. Pendidikan perguruan tinggi adalah satuan pendidikan yang padanya diselenggarakan jenjang pendidikan tinggi dimana peserta didiknya disebut mahasiswa sedangkan tenaga pendidiknya disebut dosen. Perguruan tinggi terdiri dari dua jenis yaitu perguruan tinggi negeri dan perguruan tinggi swasta. Perguruan tingi negeri di kelola oleh negara sedangkan perguruan tinggi swasta di kelola oleh yayasan (Menurut Amin, 2014: 62). Hal ini dapat digunakan sebagai indikator unuk mengukur latarbelakang pendidikan orang tua yang menempuh pendidikan SD sampai dengan perguruan tinggi.

\section{Hasil Belajar}

Menurut Sutrisno (2021: 24), hasil belajar sering disebut juga dengan istilah scholastic achievement atau academic achievement, yang artinya seluruh pencapaian hasil yang diperoleh melalui proses belajar mengajar di sekolah dinyatakan dengan bentuk angka-angka atau nilai-nilai berdasarkan tes hasil belajar yang telah ditempuh. Hal ini dudukung dengan pernyataan Skinner (Arsa, 2019: 16) bahwa hasil belajar merupakan seluruh kecakapan yang dicapai melalui proses pembelajaran di sekolah dan dinyatakan dengan angka-angka atau nilai-nilai melalui tes. Hasil belajar tersebut dipeoleh berdasarkan kemampuan, pengetahuan, sikap, keterampilan individu itu sendiri. Sedangkan Toyyibah (2017: 48) menyatakan bahwa, hasil belajar biasanya lebih terarah kepada tercapainya tujuan belajar.

Keberhasilan belajar juga tidak luput dari faktor-faktor yang mempengaruhinya. Menurut Djamarah (2015: 175-205), terdapat dua faktor yang mempengaruhi hasil belajar yaitu faktor internal dan eksternal. Internal dapat meliputi seperti bisu, tuli, gagar otak, minat, kecerdasan, bakat, motivasi, kemampuan kognitif, sedangkan eksternal dapat meliputi seperti kurikulum, program, sarana dan prasarana, guru. Suprayitno (2020: 180) menjelaskan secara lebih detail mengenai faktor yang mempengaruhi hasil belajar. Faktor internal pada dasarnya meliputi faktor fisologis dan psikologis. Faktor fisiologis sangat menunjang aktifitas belajar peserta didik. Keadaan jasmani yang sehat tentu akan sangat berbeda dengan keadaan jasmani yang kurang sehat. Hal ini berpengaruh terhadap asupan nutrisi yang cukup, makanan yang bergizi. Apabila jasmani kekurangan asupan, tentu akan mengakibatkan keadaan jasmani ngantuk dan mudah lelah. Faktor psikologis merupakan salah satu yang mendorong atau memotivasi dalam belajar diantaranya: (a) mendapatkan rasa aman, (b) memperbaiki kegagalan, (c) adanya keinginan untuk tahu, (d) agar mendapatkan simpati dari orang lain. Keluarga, sekolah dan masyarakat juga merupakan faktor yang kemungkinan besar berpengaruh terhadap hasil belajar peserta didik.

Nurjan (2016: 162) juga memberikan pendapat bahwasanya faktor yang mempengaruhi kesulitan belajar dari dari dalam diri individu berkaitan dengan fisik (cacat tubuh, kondisi yang kurang sehat, kelelahan, terganggunya konsentrasi dan pikir) dan luar diri individu berkaitan dengan intelegensi, bakat, minat, motivasi, 
kesehatan mental. Sedangkan Menurut Utomo (2015: 29), fisik berkaitan dengan kesehatan jasmani dan psikis berkaitan dengan kecerdasan. Secara eksternal, berkaitan dengan pola asuh orang tua, bahkan keadaan ekonomi keluarga. Sedangkan menurut Syah (2015: 154), faktor ekternal berkaitan dengan lingkungan sosial (masyarakat dan keluarga) maupun non sosial (gedung sekolah, tempat tinggal, alat belajar, serta waktu belajar). Hasil belajar yang digunakan pada penelitian ini berupa hasil belajar dari data sekunder, atau dokumentasi nilai belajar IPA Kelas IV SDIT Al-Madina Purworejo pada semester genap tahun ajaran 2020/2021.

\section{METODE PENELITIAN}

Penelitian ini berjenis expost facto dengan pendekatan kuantitatif. Populasi dari penelitian sebanyak 24 peserta didik, dengan teknik sempel jenuh ( semua populasi dijadikan sempel). Intrumen yang digunakan berupa lembar observasi (untuk mengukur kemandirian belajar), lembar angket (untuk mengukur latarbelakang pendidikan orang tua), dan dokumentasi (untuk mengukur hasil belajar IPA). Teknik analisis data meliputi uji prasyarat analisis dan uji hipotesis. Uji prasyarat analisis terdiri dari uji normalitas dan uji linearitas, sedangkan uji hipotesis menggunakan teknik uji regresi ganda. Objek penelitian ini dilakukan di SDIT Al-Madina Purworejo pada semester genap tahun ajaran 2020/2021.

\section{HASIL DAN PEMBAHASAN}

Deskripsi Data Penelitian

Penelitian ini dilkukan di SDIT Al-Madina Purworejo dengan jumlah populasi 24 peserta didik dengan sample semua dari jumlah populasi. Adapun data pada penelitian ini sebagai berikut: (1) data kemandirian peserta didik, (2) data latarbelakang pendidikan orang tua, dan (3) data hasil belajar IPA.

Descriptive Statistics

\begin{tabular}{|l|r|r|r|r|r|r|}
\hline & \multicolumn{1}{|c|}{$N$} & \multicolumn{1}{|c|}{ Range } & Minimum & Maximum & Mean & Std. Deviation \\
\hline$X 1$ & 24 & 7 & 4 & 11 & 8.38 & 2.081 \\
$\times 2$ & 24 & 7 & 3 & 10 & 6.29 & 2.236 \\
$Y$ & 24 & 62 & 34 & 96 & 89.17 & 12.075 \\
Valid N (listwise) & 24 & & & & & \\
\hline
\end{tabular}

Gambar 1. Deskripsi Data

Berdasarkan Gambar.1, pada variabel $\mathrm{X}_{1}$ diperoleh nilai rata-rata sebesar 8,38 dengan Standar Deviation 2,081, dan diperoleh hasil kategori variabel termasuk dalam kategori sedang dengan berada pada interval 7,3-9,4 (hasil perhitungan dari mean dan standar deviation). Pada variabel $\mathrm{X}_{2}$ diperoleh nilai rata-rata sebesar 6,29 dengan Standar Deviation 2,236, dan diperoleh hasil kategori variabel termasuk dalam kategori sedang dengan berada pada interval 5,1-7,4. Pada variabel Y diperoleh nilai rata-rata sebesar 89,17 dengan Standar Deviation 12,075, dan diperoleh hasil kategori variabel termasuk dalam kategori sangat baik dengan berada pada interval 80-100.

\section{Uji Prasyarat Analisis Data}

Salah satu syarat dalam menggunakan analisis uji hipotesis parametrik ialah menggunakan uji prasyarat analisis data. Pada penelitian ini, menggunakan uji 
hoptesis regresi ganda dengan prasyarat uji meliputi: (1) uji normalitas, dan (2) uji linieritas.

\section{Uji Normalitas Data}

Normalitas data merupakan uji yang dilakukan untuk mengetahui apakah terdapat data dari masing-masing variabel berdistribusi normal atau tidak. Perhitungan dilakukan dengan bantuan SPSS 18 PASW Statistics Viewer pada Kolmogrov-Smirnov dan di peroleh data sebagai berikut:

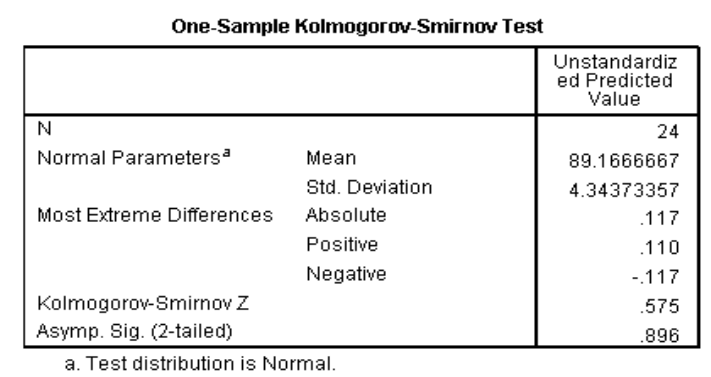

Gambar 2. Hasil Uji Normalitas

Penafsiran: jika Kolmogrov-Smirnov Z dan Asymp > 0,05, maka data penelitian distribusi normal. Hasil: diperoleh nilai Kolmogrov-Smirnov $Z$ yaitu 0,575 > 0,05 dan Asymp 0,896>0,05. Oleh karena itu dapat diambil kesimpulan bahwa data penelitian tersebut distribusi normal.

\section{Uji Linearitas Data}

Uji linieritas dimaksudkan untuk mengetahui apakah variabel bebas (X) dengan variabel terikat (Y) mempunyai pengaruh linier atau tidak. Perhitungan dilakukan dengan bantuan SPSS 18 PASW Statistics Viewer pada Anova Table dan di peroleh data sebagai berikut:

\begin{tabular}{|c|c|c|c|c|c|c|c|}
\hline \multicolumn{8}{|c|}{ ANOVA Table } \\
\hline & & & $\begin{array}{c}\text { Sum of } \\
\text { Squares }\end{array}$ & $\mathrm{df}$ & Mean Square & $\mathrm{F}$ & Sig. \\
\hline \multirow[t]{5}{*}{$Y * X 1$} & Between Groups & (Combined) & 1498.205 & 6 & 249.701 & 2.288 & .084 \\
\hline & & Linearity & 399.501 & 1 & 399.501 & 3.661 & .073 \\
\hline & & Deviation from Linearity & 1098.704 & 5 & 219.741 & 2.014 & .128 \\
\hline & Within Groups & & 1855.129 & 17 & 109.125 & & \\
\hline & Total & & 3353.333 & 23 & & & \\
\hline
\end{tabular}

Gambar 3. Hasil Uji Linieritas $\mathrm{X}_{1}$

Penafsiran: Jika nilai Deviation from Linearity $>\operatorname{sig}$ dan $F_{\text {hitung }}>F_{\text {tabel, }}$, maka terjadi hubungan yang linier dan signifikan antara $\mathrm{X}_{1}$ dengan $\mathrm{Y}$. Hasil: (1) nilai Deviation from Linearity sig yaitu $0,128>0,05$, dan (2) nilai $F_{\text {hitung }}$ diperoleh 2,014< $\mathrm{F}_{\text {tabel }} 3$,44. Oleh karena itu, dapat diambil kesimpulan bahwa ada hubungan linear dan signifikan antara variabel independen (kemandirian belajar peserta didik) terhadap variabel dependen (Hasil belajar IPA).

\begin{tabular}{|c|c|c|c|c|c|c|c|}
\hline & & & $\begin{array}{c}\text { Sum of } \\
\text { Squares }\end{array}$ & $d f$ & Mean Square & $\mathrm{F}$ & Sig. \\
\hline \multirow[t]{5}{*}{$Y * X 2$} & Between Groups & (Combined) & 198.222 & 6 & 33.037 & .178 & .979 \\
\hline & & Linearity & 42.827 & 1 & 42.827 & .231 & .637 \\
\hline & & Deviation from Linearity & 155.395 & 5 & 31.079 & .167 & .971 \\
\hline & Within Groups & & 3155.111 & 17 & 185.595 & & \\
\hline & Total & & 3353.333 & 23 & & & \\
\hline
\end{tabular}

\section{Paris Langkis}

Vol.2 Nomor 1, Agustus 2021 
Gambar 4. Hasil Uji Linieritas $\mathrm{X}_{2}$

Hasil: (1) nilai Deviation from Linearity sig yaitu 0,971 >0,05, dan (2) nilai $F_{\text {hitung }}$ diperoleh $0,167<\mathrm{F}_{\text {tabel }}$ 3,44. Oleh karena itu, dapat diambil kesimpulan bahwa ada hubungan linear dan signifikan antara variabel independen (kemandirian belajar peserta didik) terhadap variabel dependen (hasil belajar IPA).

\section{Uji Hipotesis Penelitian}

Uji hipotesis dalam penelitian ini mengunakan analisis regresi berganda untuk mengetahui pengaruh antara variabel kemandirian belajar peserta didik dan latarbelakang pendidikan orang tua terhadap hasil belajar peserta didik. Upaya dalam melihat hipotesis dari masing-masing variabel independen terhadap dependen dapat dilihat pada tabel coefficients, sedangkan tabel anova digunakan untuk melihat hipotesis secara bersama-sama. Perhitungan dilakukan dengan bantuan SPSS 18 PASW Statistics Viewer, dan hasil uji disajikan dalam gambar berikut ini:

\begin{tabular}{|c|c|c|c|c|c|c|}
\hline \multicolumn{7}{|c|}{ Coefficients $^{a}$} \\
\hline \multirow{2}{*}{\multicolumn{2}{|c|}{ Model }} & \multicolumn{2}{|c|}{ Unstandardized Coefficients } & \multirow{2}{*}{$\begin{array}{c}\begin{array}{c}\text { Standardized } \\
\text { Coefficients }\end{array} \\
\text { Beta }\end{array}$} & \multirow[b]{2}{*}{$t$} & \multirow[b]{2}{*}{ Sig. } \\
\hline & & $\mathrm{B}$ & Std. Error & & & \\
\hline 1 & (Constant) & 76.009 & 12.504 & & 6.079 & .000 \\
\hline & $\mathrm{x} 1$ & 1.983 & 1.182 & .342 & 1.677 & .108 \\
\hline & $\times 2$ & -.548 & 1.100 & -.101 & -.498 & .624 \\
\hline
\end{tabular}

Gambar 5. Hipotesis $X_{1}$ dengan $Y$ dan $X_{2}$ dengan $Y$

Hubungan Antara Kemandirian Belajar Peserta Didik $\left(\mathrm{X}_{1}\right)$ Dengan Hasil Belajar IPA (Y)

H0, tidak terdapat pengaruh antara kemandirian belajar peserta didik terhadap hasil belajar IPA kelas IV di didik SDIT Al-Madina Purworejo

Ha, terdapat pengaruh antara kemandirian belajar peserta didik terhadap hasil belajar IPA kelas IV di SDIT Al-Madina Purworejo.

Penafsiran: jika nilai beta positif dan sig $<0,05$ maka terdapat pengaruh antara variabel kemandirian belajar peserta didik $\left(\mathrm{X}_{1}\right)$ dan hasil belajar IPA kelas IV di SDIT Al-Madina Purworejo (Y). Hasil: diperoleh nilai beta positif sebesar 0,342 dan Sig $0,108>0,05$. Meski beta bernilai positif, akan tetapi hasil tidak signifikan. Oleh karena itu, dapat diambil kesimpulan bahwa tidak adanya pengaruh antara kemandirian belajar peserta didik (X1) dengan hasil belajar IPA kelas IV di SDIT AlMadina Purworejo (Y). Kontribusi yang diberikan variabel kemandirian belajar peserta didik terhadap hasil belajar peserta didik sebesar 1,02\% (r2x100\%). Asumsi peneliti terkait dengan penemuan ini yaitu pengaruh variabel lainnya yang tidak peneliti teliti, karena pada hakikatnya hasil belajar terbentuk dari beberapa faktor.

\section{Hubungan Antara Latarbelakang Pendidikan Orang Tua $\left(\mathrm{X}_{2}\right)$ Dengan Hasil Belajar IPA (Y)}

$\mathrm{HO}$, tidak terdapat pengaruh antara latarbelakang pendidikan orang tua terhadap hasil belajar IPA di SDIT Al-Madina Purworejo.

Ha, terdapat pengaruh antara latarbelakang pendidikan orang tua terhadap hasil belajar IPA kelas IV di SDIT Al-Madina Purworejo. 
Penafsiran: jika nilai beta positif dan sig $<0,05$ maka terdapat pengaruh antara variabel latarbelakang pendidikan orang tua (X2) dan hasil belajar IPA kelas IV di SDIT Al-Madina Purworejo (Y). Hasil: diperoleh nilai beta negatif sebesar -0,101 dan Sig 0,624 > 0,05. Oleh karena itu, dapat diambil kesimpulan bahwa tidak adanya pengaruh antara kemandirian belajar peserta didik (X1) dengan hasil belajar IPA kelas IV di SDIT Al-Madina Purworejo (Y). Hal ini, variabel latarbelakang pendidikan orang tua tidak memberikan kontribusi sama sekali terhadap hasil belajar peserta didik dikarenakan nilai koefisien yang negatif. Asumsi peneliti terkait dengan penemuan ini yaitu pengaruh variabel lainnya yang tidak peneliti teliti, karena pada hakikatnya hasil belajar terbentuk dari beberapa faktor.

\section{Hubungan Antara Variabel Kemandirian Belajar Peserta Didik Dan Latarbelakang Pendidikan Orang Tua Terhadap Hasil Belajar IPA Kelas IV Di SDIT Al-Madina Purworejo.}

HO, tidak terdapat pengaruh antara kemandirian belajar peserta didik dan latar belakang pendidikan orang tua terhadap hasil belajar belajar IPA kelas IV di SDIT AlMadina Purworejo.

Ha, terdapat pengaruh antara kemandirian belajar peserta didik dan latar belakang pendidikan orang tua terhadap hasil belajar IPA kelas IV di SDIT Al-Madina Purworejo.

\begin{tabular}{|c|c|c|c|c|c|c|}
\hline \multicolumn{7}{|c|}{ ANOVA ${ }^{\mathrm{B}}$} \\
\hline Model & & $\begin{array}{l}\text { Sum of } \\
\text { Squares }\end{array}$ & df & Mean Square & $\mathrm{F}$ & Sig. \\
\hline \multirow[t]{3}{*}{1} & Regression & 433.964 & 2 & 216.982 & 1.561 & $.233^{a}$ \\
\hline & Residual & 2919.369 & 21 & 139.018 & & \\
\hline & Total & 3353.333 & 23 & & & \\
\hline
\end{tabular}

b. Dependent Variable: $Y$

Gambar 6. Hipotesis $\mathrm{X}_{1}$ dan $\mathrm{X}_{2}$ terhadap $\mathrm{Y}$

Penafsiran: jika $F_{\text {hitung }}>F_{\text {tabel }}$ dan nilai Sig $<0,05$ maka terdapat pengaruh antara variabel kemandirian belajar peserta didik $\left(\mathrm{X}_{1}\right)$ dan latarbelakang pendidikan orang tua $\left(\mathrm{X}_{2}\right)$ terhadap hasil belajar IPA kelas IV di SDIT Al-Madina Purworejo (Y).

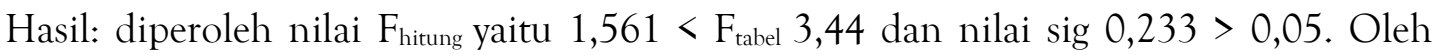
karena itu, dapat diambil kesimpulan bahwa tidak adanya pengaruh antara kemandirian belajar peserta didik $\left(\mathrm{X}_{1}\right)$ dan latarbelakang pendidikan orang tua $\left(\mathrm{X}_{2}\right)$ terhadap hasil belajar IPA kelas IV di SDIT Al-Madina Purworejo (Y). Kecilnya kontribusi yang diberikan variabel kemandirian belajar $\left(\mathrm{X}_{1}\right)$ dan tidak adanya kontribusi yang diberikan variabel latarbelakang pendidikan orang tua $\left(\mathrm{X}_{2}\right)$, menjadi asumsi peneliti terkait tidak adanya pengaruh secara bersama-sama antara kemandirian belajar $\left(\mathrm{X}_{1}\right)$ dan latarbelakang pendidikan orang tua $\left(\mathrm{X}_{2}\right)$ terhadap hasil belajar IPA (Y).

\section{E. KESIMPULAN}

Berdasarkan uraian yang telah dipaparkan, maka dapat diambil kesimpulan: (1) tidak terdapat pengaruh antara kemandirian belajar peserta didik terhadap hasil belajar peserta didik kelas IV SDIT Al-Madina Purworejo, dengan nilai beta positif sebesar 0,342 dan Sig 0,108>0,05 serta kontribusi yang diberikan sebesar 1,02\%, (2) tidak terdapat pengaruh antara latarbelakang pendidikan orang tua terhadap hasil 
belajar kelas IV SDIT Al-Madina Purworejo, dengan nilai beta negatif sebesar -0,101 dan Sig 0,624>0,05 serta variabel latarbelakang pendidikan orang tua tidak memberikan kontribusi sama sekali dikarenakan koefisien yang negatif, (3) tidak terdapat pengaruh antara kemandirian belajar peserta didik dan latarbelakang pendidikan orang tua terhadap hasil belajar kelas IV SDIT Al-Madina Purworejo,

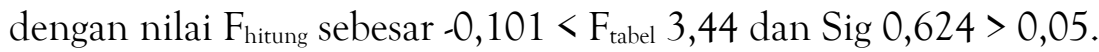

\section{F. SARAN DAN UCAPAN TERIMAKASIH}

Hasil penelitian ini memberikan saran kepada penulis lain dengan menindak lanjuti lebih jauh penelitian serupa. Ucapatan terimakasih juga peneliti sampaikan kepada Universitas Muhammadiyah Purworejo, yang telah memberikan kesempatan kepada peneliti dalam menempuh studi sarjana ini.

\section{DAFTAR PUSTAKA}

Amin, Rifqi, A. (2014). Sistem Pembelajaran Pendidikan Agama Islam Pada Perguruan Tinggi Umum. Yogyakarta: CV Budi Utama.

Arsa, Suka, Putu I. (2015). Belajar dan Pembelajaran. Yogyakarta Media Akademi.

Cholifah, Nur Tety., Degeng, Sudana, Nyoman I., \& Utaya, Sugeng. (2016). Pengaruh Tingkat Latarbelakang Pendidikan Orang Tua Dan Gaya Belajar Terhada Hasil Belajar Siswa Pada Kels IV SDN Kecamatan Sananwetan Kota Blitar. Jurnal Pendidikan. 1(5): 486.

Chomaidi, dan Salamah. (2018). Pendidikan dan Pengajaran Strategi Pembelajaran Sekolah. Jakarta: PT Grasindo.

Djamaluddin. A. 2014. Filsafat Pendidikan. Istiqra, 1(2), 129-135.

Djamarah, Syaiful Bahri. (2015). Psikologi Belajar. Jakarta: Rineka Cipta.

Imron, Ali. (2016). Pengaruh Kemandirian Belajar dan Minat Terhadap Prestasi Belajar Pelajaran Ilmu Pengetahuan. Jurnal Ilmiah Pendidikan. 3(1): 143-144.

Kemendikbud. (2020).https://pusdiklat.kemdikbud.go.id/surat-edaran-mendikbud-no-4tahun-2020-tentang-pelaksanaan-kebijakan-pendidikan-dalam-masa-daruratpenyebaran-corona-virus-disease-covid-1-9/. pdf 13 Oktober 2020.

Kunandar. (2013). Penilaian Autentik (Penilaian Hasil Belajar Peserta Didik Berdasarkan Kurikulum 2013). Jakarta: PT Raja Grafindo Persada.

Ningsih, Rita., Nurrahmah., \& Arfatin. (2017). Pengaruh Kemandirian Belajar \& Perhatian Orang Tua Terhadap Prestasi Belajar Matematika. Jurnal Formatif. 6(1): 76.

Nurjan. S. 2016. Psikologi Belajar. Wade Group: Ponorogo.

Ranti, Gadih Mayang., Budiarti, Indah.,Trisna, Nawa Benny. (2017). Pengaruh Kemandirian Belajar (Self Regulated Learning) Terhadap Hasil Belajar Mahasiswa Pada Mata Kuliah Struktur Aljabar. Jurnal Pendidikan Matematika. 3(1): 75.

Sisdiknas. (2003). UU Nomor 20 Tentang Sistem Pendidikan Nasional. Diunduh dari luk.staff.ugm.ac.id/atur/UU20-2003Sisdiknas. pdf pada tanggal 13 Oktober 2020.

Slameto. (2015). Belajar dan Faktor-faktor Yang Mempengaruhi. Jakarta: PT Rineka Cipta.

Paris Langkis

Vol.2 Nomor 1, Agustus 2021 
Sudjana, Nana. (2012). Penilaian Hasil Proses Belajar Mengajar. Bandung: PT Remaja Rosdakarya.

Suhandi, Andi., Kurniasri, Dini. (2019). Meningkatkan Kemandirian Siswa Melalui Model Pembelajaran Kontekstual Di Kelas IV Sekolah Dasar. Jurnal Genatala Pendidikan Dasar. 4(1). 126.

Suharno, Agung. (2016). Penggunaan Pendekatan Pembelajaran Kooperatif STAD Dalam Usaha Meningkatkan Hasil Belajar Pelajaran Sosiologi Pada Siswa Kelas XB SMA Negeri 1 Tangen Semester 1 Tahun Pelajaran 2015/2016. Jurnal Konvergensi. 5(1). 12.

Suprayitno, Adi. (2020). Menyusun PTK Era 4.0. Yogyakarta: CV Budiutama.

Sutrisno. (2021). Meningkatkan Minat $\mathcal{E}$ Hasil Belajar TIK Materi Topologi Jaringan Dengan Media Pembelajaran. Malang: Ahlimedia Press (Anggota IKAPI: 264/JTI/2020).

Syah, Muhibbin. (2015). Psikologi Belajar. Jakarta: Rajawali Pers.

Syah, Muhibbin. (2019). Psikologi Pendidikan. Bandung: PT Remaja Rosdakarya.

Toyyibah, Ibay. (2017). Cara-Cara Belajar Menurut Kecerdasan Dan Potensi Genetik. Jakarta: PT Gramedia.

Utomo, L.W. (2015). Psikologi Pendidikan. Purworejo: Universitas Muhammadiyah Purworejo.

Wahyuningsih, Diana Dewi. (2020). Panduan Untuk Konselor Teknik Self Management Dalam Bingkai Konseling Coknitive Behavior Untuk Meningkatkan Kemandirian Belajar Siswa SMP. Jawa Tengah: CV Sarnu Untung. 